\title{
Short communication: Antiproliferative effect of 8 different Lactobacillus strains on K562 cells
}

\author{
Yanfeng Tuo, ${ }^{*}$ Shujuan Jiang, ${ }^{*}$ Fang Qian, ${ }^{*}$ Guangqing Mu, ${ }^{*}{ }^{1}$ Peng Liu, ${ }^{*}$ Yuanji Guo, ${ }^{*}$ and Changlu Mał \\ *School of Food Science and Technology, Dalian Polytechnic University, Dalian, 116034, P.R. China \\ †Synergetic Innovation Center of Food Safety and Nutrition, Northeast Agricultural University, Harbin, 150030, P.R.China \\ łBeijing Vocational College of Agriculture, Beijing, 102442, P.R. China
}

\section{ABSTRACT}

Some strains of Lactobacillus genus have antiproliferative activities against cancer cells. However, until now, the exact effector molecules of Lactobacillus strains with anticancer activity have not been identified. The aim of the present study was to explore which fraction of the Lactobacillus cells exerts the highest antiproliferative effect. For this purpose, the heat-killed bacterial cells, bacterial cell wall extract, and genomic DNA of 8 Lactobacillus strains were prepared to assess their antiproliferative activities against human myeloid leukemia cell lines K562. The heat-killed bacterial cells of the 8 lactobacilli strains exerted antiproliferative effect on K562 cells, and the inhibition rates exerted by the heat-killed bacterial cells of the strains G15AL, M5AL, SB31AL, SB5AL, and T3AL were significantly higher than those exerted by the cell walls and genomic DNA of the strains. The bacterial DNA of G15AL exerted higher antiproliferative effect on K562 cells. The exact effector molecules and the effect mechanism of the strains should be further explored for the application of these strains as probiotic strains or bioactive probiotic molecules.

Key words: Lactobacillus, antiproliferative effect, K562 cell

\section{Short Communication}

Some indirect proofs based largely on laboratory studies showed that lactic acid bacteria (LAB) had anticancer activity. Researchers proved that Lactobacillus casei (Tomita et al., 1994), Lactobacillus rhamnosus (Goldin et al., 1996), Lactobacillus acidophilus (McIntosh et al., 1999), and Bifidobacterium longum (Reddy and Rivenson, 1993; Singh et al., 1997) could inhibit the proliferation of tumors in rodent bodies induced by mutagen or by transplantation. Whole bacteria cells, bacteria cell wall, or other cellular components of

Received August 21, 2014.

Accepted October 5, 2014.

${ }^{1}$ Corresponding author: gq6552002@aliyun.com
LAB could inhibit the growth of cancer cells (Fichera and Giese, 1994; Kim et al., 2002). The antiproliferative activity of LAB against the growth of tumor cells might be due to their cytotoxic and apoptotic effects on cancer cells in a dose- and time-dependent manner (Fichera and Giese, 1994; Puertollano et al., 2009; Thirabunyanon et al., 2009).

Our previous study reported that $7 \mathrm{~L}$. rhamnosus strains isolated from Chinese traditional fermented foods could inhibit the growth of human colonic cancer cell line HT-29 (Tuo et al., 2010). In the current study, we assessed the antiproliferative effect of the cellular components (i.e., heat-killed whole bacteria cells, cell wall, and bacterial genomic DNA) of 7 Lactobacillus strains and another strain from human feces on human myeloid leukemia cell lines K-562.

Information about the 8 Lactobacillus strains used in our study is listed in Table 1. The strains were cultured in de Man, Rogosa, and Sharpe (MRS) broth at $37^{\circ} \mathrm{C}$ and stored at $4^{\circ} \mathrm{C}$. The strains were subcultured twice at $37^{\circ} \mathrm{C}$ for $18 \mathrm{~h}$ before use. The counts $(\mathrm{cfu} / \mathrm{mL})$ of the strains were determined by plating serial 10 -fold dilution into MRS-agar.

To prepare heat-killed bacterial cells of the Lactobacillus strains, bacterial cells from 18-h Lactobacillus strain cultures were harvested by centrifugation at $5,000 \times g$ for $10 \mathrm{~min}$ at $4^{\circ} \mathrm{C}$ (Micro fuge-18, Low Temperature Superspeed Centrifuge, Beckman Coulter, Brea, CA) and washed twice with PBS buffer ( $\mathrm{pH}$ 7.2). Heat treatment was carried out according to the method of Lankaputhra and Shah (1998). The cell suspensions in PBS containing $10^{9} \mathrm{cfu} / \mathrm{mL}$ were heat treated in test tubes $(15 \times 150 \mathrm{~mm})$ by immersion in a boiling water bath at $100^{\circ} \mathrm{C}$ for $20 \mathrm{~min}$. After heat treatment, the cells were cooled immediately in ice water and vortexed for about 5 min to break any coagulum formed during heating. Then the heat-killed bacterial cells were resuspended in RPMI-1640 medium (Thermo Scientific HyClone, Thermo Fisher Scientific Inc., Waltham, MA) at a concentration of $2 \times 10^{9} \mathrm{cfu} / \mathrm{mL}$. They were then plated in MRS agar to determine the efficacy of heat treatment. The cell wall of the Lactobacillus strains was prepared 
Table 1. Lactobacillus strains used in this study

\begin{tabular}{lll}
\hline Strain & Species & Origin ${ }^{1}$ \\
\hline SB5AL & Lactobacillus rhamnosus & Traditional fermented yak milk food; Subei, Gansu Province, China \\
SB31AL & L. rhamnosus & Traditional fermented yak milk food; Subei, Gansu Province, China \\
M5AL & Lactobacillus paracasei ssp. paracasei & Traditional koumiss; Yili, Sinkiang \\
J23ANL & L. paracasei ssp. paracasei & Traditional fermented vegetable juice; Lanzhou, Gansu Province, China \\
J5ANL & L. rhamnosus & Traditional fermented vegetable juice; Lanzhou, Gansu Province, China \\
G15AL & L. paracasei ssp. paracasei & Traditional fermented yak milk food; Gannan, Gansu Province, China \\
IN1ANL & L. rhamnosus & Human feces from healthy infant, Haerbin, Heilongjiang Province, China \\
T3AL & Lactobacillus coryniformis ssp. torquens & Traditional yak milk cheese; Lhasa, Tibet \\
\hline
\end{tabular}

${ }^{1}$ The fermented foods were made by the local people using traditional method under local climate and environmental conditions.

according to the method described by Heumann et al. (1994) and Amrouche et al. (2006). Briefly, after $18 \mathrm{~h}$ of incubation, the bacteria cells from $50 \mathrm{~mL}$ of lactobacilli culture were harvested by centrifugation $(5,000 \times g, 10$ $\min , 4^{\circ} \mathrm{C}$ ) and washed twice with PBS (pH 7.2). The pelleted cells were suspended in $10 \mathrm{~mL}$ of purified water and broken immediately with 3 or 4 volumes of $\mathrm{SiO}_{2}$ beads (diameter $=0.05-0.1 \mathrm{~mm}$ ) in a vortex mixer at maximum speed for $30 \mathrm{~min}$ at $4^{\circ} \mathrm{C}$. Unbroken bacterial cells and $\mathrm{SiO}_{2}$ beads were separated from the suspension by low-speed centrifugation at $2,000 \times g$ for $15 \mathrm{~min}$ at $4^{\circ} \mathrm{C}$. The homogenate was recentrifuged at $30,000 \times$ $g$ for 30 min at $4^{\circ} \mathrm{C}$ to pellet cell wall. Cell wall material was resuspended in $2 \mathrm{~mL}$ of purified water. The protein content of the cell wall extracts was determined by the Lowry method (Lowry et al., 1951). Then the cell wall was diluted in RPMI-1640 medium. Genomic DNA of the Lactobacillus strains incubated for $18 \mathrm{~h}$ at $37^{\circ} \mathrm{C}$ was purified by phenol-chloroform-isoamyl alcohol extraction method (Ghadimi et al., 2008). The concentration and purity of all DNA preparations were determined by measuring absorbance at 230, 260, and $280 \mathrm{~nm}$ [optical density $(\mathbf{O D})_{230}, \mathrm{OD}_{260}$, and $\mathrm{OD}_{280}$, respectively]. Only the DNA with the $\mathrm{OD}_{260 / 280}$ ratio $>1.8$ and $\mathrm{OD}_{260 / 230} \geq 2$ was used. The DNA was diluted in RPMI-1640 medium and stored at $-20^{\circ} \mathrm{C}$.

Experiments to evaluate the antiproliferative effects of the Lactobacillus strain cell fractions on human myeloid leukemia cell line K562 were carried out. Human myeloid leukemia cell lines K-562 were obtained from the Cancer Institute of the Chinese Academy of Medical Science (Beijing, China). The K-562 cells were cultured in complete RPMI-1640 medium (Thermo Scientific HyClone, Beverly, MA), supplemented with $10 \%$ (vol/vol) inactivated $\left(56^{\circ} \mathrm{C}, 30 \mathrm{~min}\right)$ fetal calf serum (Sijiqing Co. Ltd., Hangzhou, China), and a 1\% (vol/ vol) mixture of penicillin $(10,000 \mathrm{IU} / \mathrm{mL})$ and streptomycin $(10,000 \mu \mathrm{g} / \mathrm{mL}$; Solarbio Co. Ltd., Beijing, China) in a humidified atmosphere of $5 \% \mathrm{CO}_{2}$ and $95 \%$ air at $37^{\circ} \mathrm{C}$. The K-562 cells were incubated for $15 \mathrm{~d}$ to become fully differentiated. Then cell viability was assessed by trypan-blue dye (0.2\%) in PBS ( $\mathrm{pH} 7.2)$ and the cell number was determined by hemocytometer. Cultures with $\geq 80 \%$ cell viability were analyzed for subsequent assays. The K-562 cells were added into 96-well plates (Corning Inc., Corning, NY) at 100 $\mu \mathrm{L}\left(1 \times 10^{4}\right.$ cells $)$ per well. The heat-killed bacterial cells, cell wall, and genomic DNA of the lactobacilli were diluted in complete RPMI-1640 medium and then added into the plates. The final concentrations of heatkilled bacteria cells were $1 \times 10^{5}, 1 \times 10^{6}$, and $1 \times$ $10^{7} \mathrm{cfu} / \mathrm{mL}$, corresponding to the ratios of bacteria to K562 cells of 1:1, 10:1, and 100:1, respectively. The final protein concentrations of cell wall were 10, 20, and $40 \mu \mathrm{g}$ of protein $/ \mathrm{mL}$, and the final concentrations of bacterial genomic DNA were 25, 50, and $100 \mu \mathrm{g} /$ $\mathrm{mL}$, respectively. Each assay was repeated 6 times. The control wells were without bacterial components. The test and control wells were supplemented with complete RPMI-1640 medium up to $110 \mu \mathrm{L}$ per well. The plates were incubated in a humidified atmosphere of $5 \% \mathrm{CO}_{2}$ and $95 \%$ air at $37^{\circ} \mathrm{C}$ for $68 \mathrm{~h}$. Subsequently, $20 \mu \mathrm{L}$ of 3-(4,5-dimethylthiazol-2-yl)-2,5-diphenyltetrazolium bromide (MTT, M5655, Sigma-Aldrich Co., St. Louis, $\mathrm{MO}$ ) at a concentration of $5 \mathrm{mg} / \mathrm{mL}$ in PBS ( $\mathrm{pH} 7.4$ ) was added into each well and the plates were incubated for another $4 \mathrm{~h}$. To dissolve the dark formazan crystals, $150 \mu \mathrm{L}$ of acidification isopropyl alcohol (SDS, $20 \mathrm{~g} ; 1$ $M \mathrm{HCl}, 2 \mathrm{~mL}$; isopropyl alcohol, $10 \mathrm{~mL}$; H2O, $100 \mathrm{~mL}$ ) was added into each well and the plates were incubated for another $3 \mathrm{~h}$. The OD was determined on a spectrophotometric microplate reader (Bio-Rad-500, Bio-Rad Laboratories Inc., Hercules, CA) at a test wavelength of $570 \mathrm{~nm}$. Results were presented as the inhibition rate, calculated using the equation

$$
\text { Inhibition rate }=[1-(\text { absorbance in test well }) /
$$$$
\text { (absorbance in control well) }] \times 100 \% \text {. }
$$

Antiproliferative assays were performed in triplicate. Statistical analyses were carried out with SPSS 14.0 for Windows (SPSS Inc., Chicago, IL). Significant differences between treatments were tested by ANOVA 
Table 2. Inhibition rate of K562 by heat-killed whole bacterial cell of the Lactobacillus strains ${ }^{1}$

\begin{tabular}{|c|c|c|c|}
\hline \multirow{2}{*}{$\begin{array}{l}\text { Lactobacillus } \\
\text { strain (cfu/mL) }\end{array}$} & \multicolumn{3}{|c|}{ Concentration of heat-killed bacteria (strain:cell) } \\
\hline & $1: 1$ & $10: 1$ & $100: 1$ \\
\hline G15AL & $22.7 \pm 2.1^{\mathrm{a}, \mathrm{A}}$ & $23.0 \pm 2.9^{\mathrm{a}, \mathrm{A}}$ & $25.9 \pm 1.1^{\mathrm{b}, \mathrm{A}}$ \\
\hline IN1ANL & $3.8 \pm 0.4^{\mathrm{d}, \mathrm{C}}$ & $9.6 \pm 1.1^{\mathrm{c}, \mathrm{B}}$ & $12.8 \pm 0.6^{\mathrm{c}, \mathrm{A}}$ \\
\hline J23ANL & $6.0 \pm 2.1^{\mathrm{cd}, \mathrm{A}}$ & $6.8 \pm 2.3^{\mathrm{c}, \mathrm{A}}$ & $3.3 \pm 1.1^{\mathrm{e}, \mathrm{B}}$ \\
\hline J5ANL & $4.0 \pm 0.9^{\mathrm{d}, \mathrm{B}}$ & $2.9 \pm 1.1^{\mathrm{d}, \mathrm{C}}$ & $7.0 \pm 1.3^{\mathrm{d}, \mathrm{A}}$ \\
\hline M5AL & $8.2 \pm 0.2^{\mathrm{c}, \mathrm{B}}$ & $12.7 \pm 0.9^{\mathrm{b}, \mathrm{A}}$ & $5.3 \pm 1.1^{\mathrm{d}, \mathrm{C}}$ \\
\hline SB31AL & $13.1 \pm 1.7^{\mathrm{b}, \mathrm{A}}$ & $7.3 \pm 0.9^{\mathrm{c}, \mathrm{B}}$ & $0.8 \pm 0.4^{\mathrm{f}, \mathrm{D}}$ \\
\hline SB5AL & $13.2 \pm 1.1^{\mathrm{b}, \mathrm{A}}$ & $1.0+0.0$ & $0.0 \pm 0.4$ \\
\hline T3AL & $15.1 \pm 2.1^{\mathrm{b}, \mathrm{D}}$ & $20.1 \pm 2.6^{\mathrm{a}, \mathrm{C}}$ & $31.2 \pm 1.7^{\mathrm{a}, \mathrm{A}}$ \\
\hline
\end{tabular}

followed by Fisher's least significant difference method with a level of significance of $P<0.05$.

The inhibition rates of K562 cells by the heat-killed bacterial cells of the 8 Lactobacillus strains at different concentrations are shown in Tables 2. The maximal inhibition rates of K-562 cells by the heat-killed bacterial cells of the strains G15L, IN1ANL, J5ANL, and T3AL were obtained at a concentration of $1 \times 10^{7} \mathrm{cfu} / \mathrm{mL}$. The inhibition rate of K-562 cells by the heat-killed bacteria of the strain T3AL was $30.0 \%$ and significantly higher $(P<0.05)$ than those achieved by other strains.

The inhibition rates of K-562 cells by the cell walls of the Lactobacillus strains at different concentrations are shown in Table 3. The cell walls of the strains J23ANL, J5ANL, and SB31AL had no effect on the proliferation of K562 cells. The cell walls of the strain T3AL exerted the highest antiproliferative effect on K-562 cells.

The inhibition rates of K-562 cells by the genomic DNA of the Lactobacillus strains at different concentrations are shown in Table 4. Only the genomic DNA of

Table 3. Inhibition rate of K562 by bacterial cell wall of the Lactobacillus strains ${ }^{1}$

\begin{tabular}{|c|c|c|c|}
\hline \multirow{2}{*}{$\begin{array}{l}\text { Lactobacillus } \\
\text { strain }\end{array}$} & \multicolumn{3}{|c|}{$\begin{array}{c}\text { Concentration of bacterial cell wall } \\
(\mu \mathrm{g} \text { of } \operatorname{protein} / \mathrm{mL})\end{array}$} \\
\hline & 10 & 20 & 40 \\
\hline G15AL & $17.2 \pm 1.8^{\mathrm{a}, \mathrm{A}}$ & $15.9 \pm 2.3^{\mathrm{c}, \mathrm{A}}$ & $8.1 \pm 0.6^{\mathrm{c}, \mathrm{B}}$ \\
\hline IN1ANL & $5.0 \pm 0.7^{\mathrm{c}, \mathrm{C}}$ & $20.4 \pm 1.1^{\mathrm{b}, \mathrm{A}}$ & $17.0 \pm 0.6^{\mathrm{b}, \mathrm{B}}$ \\
\hline J23ANL & - & - & - \\
\hline J5ANL & - & - & - \\
\hline M5AL & $1.0 \pm 0.2^{\mathrm{d}, \mathrm{B}}$ & $0.6 \pm 0.2^{\mathrm{e}, \mathrm{B}}$ & $8.6 \pm 0.9^{\mathrm{c}, \mathrm{A}}$ \\
\hline SB31AL & - & $8.6 \pm 1.2^{\mathrm{d}, \mathrm{B}}$ & $5.6 \pm 1.3^{\mathrm{d}, \mathrm{A}}$ \\
\hline SB5AL & $1.5 \pm 0.2^{\mathrm{d}, \mathrm{A}}$ & $1.7 \pm 0.4^{\mathrm{e}, \mathrm{A}}$ & - \\
\hline T3AL & $12.7 \pm 0.6^{\mathrm{b}, \mathrm{B}}$ & $25.0 \pm 1.3^{\mathrm{a}, \mathrm{A}}$ & $22.7 \pm 2.6^{\mathrm{a}, \mathrm{A}}$ \\
\hline
\end{tabular}

${ }^{\mathrm{a}-\mathrm{e}}$ Values with different lowercase superscripts in each column are significantly different $(P<0.05)$.

${ }^{\mathrm{A}, \mathrm{B}}$ Values with different uppercase superscripts in each row are significantly different $(P<0.05)$.

${ }^{1}$ Values are means of triplicate determinations $\pm \mathrm{SD}$. the strains G15AL, M5AL, and SB31L had the antiproliferative effects on K-562 cells. The genomic DNA of $\mathrm{G} 15 \mathrm{AL}$ at $50 \mu \mathrm{g}$ of $\mathrm{DNA} / \mathrm{mL}$ exerted the highest antiproliferative effect on K-562 cells. The heat-killed bacterial cells and cell walls of the strain T3AL exerted the highest antiproliferative effect on K562 cells, whereas the genomic DNA of the strain G15AL exerted the highest antiproliferative effect on K-562 cells.

In our study, the heat-killed bacterial cells of the 8 Lactobacillus strains exerted antiproliferative effect on K562 cells, the maximal inhibition rates exerted by the heat-killed bacterial cells of the strains T3AL and G15AL were significantly higher $(P<0.05)$ than those of other strains, and the inhibition rates exerted by the heat-killed bacterial cells of the strains G15AL, M5AL, SB31AL, SB5AL, and T3AL were significantly higher $(P<0.05)$ than those exerted by the cell walls and genomic DNA of the strains. Except the strains G15AL and M5AL, other strains' genomic DNA did not exert antiproliferative effect on K562 cells, and the cell walls

Table 4. Inhibition rate of K562 by bacterial DNA of the Lactobacillus strains $^{1}$

\begin{tabular}{lccc}
\hline & \multicolumn{3}{c}{ Genomic DNA $(\mu \mathrm{g}$ of DNA $/ \mathrm{mL})$} \\
\cline { 2 - 4 } $\begin{array}{l}\text { Lactobacillus } \\
\text { strain }\end{array}$ & 25 & 50 & 100 \\
\hline G15AL & - & $25.9 \pm 2.6^{\mathrm{a}, \mathrm{A}}$ & $12.6 \pm 1.7^{\mathrm{a}, \mathrm{B}}$ \\
IN1ANL & - & - & - \\
J23ANL & - & - & - \\
J5ANL & - & - & - \\
M5AL & $3.9 \pm 0.6^{\mathrm{a}, \mathrm{B}}$ & $8.4 \pm 0.4^{\mathrm{b}, \mathrm{A}}$ & $2.9 \pm 0.8^{\mathrm{b}, \mathrm{B}}$ \\
SB31AL & $4.2 \pm 0.8^{\mathrm{a}}$ & - & - \\
SB5AL & - & - & - \\
T3AL & - & -
\end{tabular}

a,b Values with different lowercase superscripts in each column are significantly different $(P<0.05)$.

${ }^{\mathrm{A}, \mathrm{B}}$ Values with different uppercase superscripts in each row are significantly different $(P<0.05)$.

${ }^{1}$ Values are means of triplicate determinations $\pm \mathrm{SD}$. 
of the strains J23ANL and J5ANL had no antiproliferative effects.

It was reported that the metabolites, entire bacterial cells, cell wall peptidoglycan, teichoic acid, and cytoplasm of some Lactobacillus strains could exert antiproliferative effect on cancer cells (Fichera and Giese, 1994; Choi et al., 2006; Lee et al., 2008; Thirabunyanon et al., 2009; Liu et al., 2011). In the current study, we found that the 8 Lactobacillus strains and their bacterial compounds had different antiproliferative activities, which was similar to other research (Tuo et al., 2010; Orlando et al., 2012). Among them, entire heat-killed bacterial cells and bacterial cell wall had higher antiproliferative activities; thus, we concluded that the probiotic effector molecules reside in the bacterial cell envelope. However, we do not know which exert compound plays a major role in antiproliferative activities. The European Food Safety Agency has deemed the vast majority of probiotic health claims to be insufficient due to the lack of biomarkers to demonstrate a cause-effect relationship (EFSA, 2009). This has urged the scientific community to unravel the molecular characteristics of probiotics and identify the effector molecules underlying the clinical effects of probiotics (Lee et al., 2013).

The antiproliferative activities of the strains against K562 may be ascribed to the apoptotic effect. It was reported that entire bacterial cells, bacterial homogenate, and cell wall extract of Lactobacillus strains could induce the apoptosis of cancer cells (Choi et al., 2006; Russo et al., 2007). Altonsy et al. (2010) reported that L. rhamnosus GG and Bifidobacterium lactis Bb12 played beneficial roles in protection against colon cancer by exerting a mild apoptotic effect. The effects of the strains on the cell cycles, mitochondrial transmembrane potential, and cytochrome C of K562 cells will be further studied to explore whether the strains induced the apoptosis of the K562 cells.

In conclusion, the heat-killed bacterial cells, cell wall, and genomic DNA of 8 Lactobacillus strains showed different antiproliferative activities against K562 cells, among which the heat-killed bacterial cells and cell walls of the strain T3AL exerted a higher antiproliferative effect on K562 cells. The exact effector molecules and the effect mechanism of the strains should be further explored for the application of these strains as probiotic strains or bioactive probiotic molecules.

\section{ACKNOWLEDGMENTS}

This work was financially supported by National Science \& Technology Pillar Program during the Twelfth Five-year Plan Period (2013BAD18B09; Beijing, China), Liaoning Province Science Plan Projects (2014026018;
Shenyang, China), and Beijing Agriculture Science \& Technology Program (20140139; Beijing, China).

\section{REFERENCES}

Altonsy, M. O., S. C. Andrews, and K. M. Tuohy. 2010. Differential induction of apoptosis in human colonic carcinoma cells (Caco2) by Atopobium, and commensal, probiotic and enteropathogenic bacteria: Mediation by the mitochondrial pathway. Int. J. Food Microbiol. 137:190-203.

Amrouche, T., Y. Boutin, G. Prioult, and I. Fliss. 2006. Effects of bifidobacterial cytoplasm, cell wall and exopolysaccharide on mouse lymphocyte proliferation and cytokine production. Int. Dairy J. 16:70-80.

Choi, S. S., Y. Kim, K. S. Han, S. You, S. Oh, and S. H. Kim. 2006. Effects of Lactobacillus strains on cancer cell proliferation and oxidative stress in vitro. Lett. Appl. Microbiol. 42:452-458.

2009. Scientific opinion on the substantiation of health claims related to non characterised microorganisms pursuant to Article 13(1) of Regulation (EC) No 1924/2006. EFSA J. 7:1247.

Fichera, G. A., and G. Giese. 1994. Non-immunologically-mediated cytotoxicity of Lactobacillus casei and its derivative peptidoglycan against tumor cell lines. Cancer Lett. 85:93-103.

Ghadimi, D., R. Fölster-Holst, M. De Vrese, P. Winkler, K. J. Heller, and J. Schrezenmeir. 2008. Effects of probiotic bacteria and their genomic DNA on TH1/TH2-cytokine production by peripheral blood mononuclear cells (PBMCs) of healthy and allergic subjects. Immunobiology 213:677-692.

Goldin, B. R., L. J. Gualtieri, and R. P. Moore. 1996. The effect of Lactobacillus GG on the initiation and promotion of DMH-induced intestinal tumors in the rat. Nutr. Cancer 25:197-204.

Heumann, D., C. Barras, A. Severin, M. P. Glauser, and A. Tomasz. 1994. Gram-positive cell walls stimulate synthesis of tumor necrosis factor alpha and interleukin- 6 by human monocytes. Infect. Immun. 62:2715-2721

Kim, J. Y., H. J. Woo, Y. S. Kim, and H. J. Lee. 2002. Screening for antiproliferative effects of cellular components from lactic acid bacteria against human cancer cell lines. Biotechnol. Lett. 24:1431-1436.

Lankaputhra, W. E. V., and N. P. Shah. 1998. Antimutagenic properties of probiotic bacteria and of organic acids. Mutat. Res. 397:169-182.

Lee, K., S. Jang, M. J. Kim, J. H. Kim, M. J. Chung, K. J. Kim, and N. J. Ha. 2008. Anti-proliferative effects of Bifidobacterium adolescentis SPM0212 extract on human colon cancer cell lines. BMC Cancer 8:310.

Lee, I. C., S. Tomita, M. Kleerebecem, and P. A. Bron. 2013. The quest for probiotic effector molecules-Unraveling strain specificity at the molecular level. Pharmacol. Res. 69:61-74.

Liu, C. T., F. J. Chu, C. C. Chou, and R. C. Yu. 2011. Antiproliferative and anticytotoxic effects of cell fractions and exopolysaccharides from Lactobacillus casei 01. Mutat. Res. 721:157-162.

Lowry, O. H., N. J. Rosebrough, A. L. Farr, and R. J. Randall. 1951. Protein measurement with the folin phenol reagent. J. Biol. Chem. 193:265-275.

McIntosh, G. H., P. J. Royle, and M. J. Playne. 1999. A probiotic strain of L.acidophilus reduces DMH-induced large intestinal tumors in male Sprague-Dawley rats. Nutr. Cancer 35:153-159.

Orlando, A., M. G. Refolo, C. Messa, L. Amati, P. Lavermicocca, V. Guerra, and F. Russo. 2012. Antiproliferative and proapoptotic effects of viable or heat-killed Lactobacillus paracasei IMPC2.1 and Lactobacillus rhamnosus GG in HGC-27 gastric and DLD-1 colon cell lines. Nutr. Cancer 64:1103-1111.

Puertollano, E., M. A. Puertollano, L. Cruz-Chamorro, G. Á. De Cienfuegos, A. Ruiz-Bravo, and M. A. de Pablo. 2009. Effects of concentrated supernatants recovered from Lactobacillus plantarum on Escherichia coli growth and on the viability of a human promyelocytic cell line. J. Appl. Microbiol. 106:1194-1203. 
Reddy, B. S., and A. Rivenson. 1993. Inhibitory effect of Bifidobacterium longum on colon, mammary, and liver carcinogenesis induced by 2-amino-3-methylimidazo [4, 5-f] quinoline, a food mutagen. Cancer Res. 53:3914-3918.

Russo, F., A. Orlando, M. Linsalata, A. Cavallini, and C. Messa. 2007. Effects of Lactobacillus Rhamnosus GG on the cell growth and polyamine metabolism in HGC-27 human gastric cancer cells. Nutr. Cancer 59:106-114.

Singh, J., A. Rivenson, M. Tomita, S. Shimamura, N. Ishibashi, and B. S. Reddy. 1997. Bifidobacterium longum, a lactic acid-producing intestinal bacterium inhibits colon cancer and modulates the intermediate biomarkers of colon carcinogenesis. Carcinogenesis 18:833-841.
Thirabunyanon, M., P. Boonprasom, and P. Niamsup. 2009. Probiotic potential of lactic acid bacteria isolated from fermented dairy milks on antiproliferration of colon cancer cells. Biotechnol. Lett. $31: 571-576$

Tomita, K., H. Akaza, K. Nomoto, T. Yokokura, H. Matsushima, Y. Homma, and Y. Aso. 1994. Influence of Lactobacillus casei on rat bladder carcinogenesis. Jpn. J. Urol. 85:655-663.

Tuo, Y. F., L. W. Zhang, H. X. Yi, Y. C. Zhang, and W. Q. Zhang, 2010. Antiproliferative effect of wild Lactobacillus strains isolated from fermented foods on HT-29 cells. J. Dairy Sci. 93:2362-2366. 